\title{
Drug Delivery System
}

review article

\section{抗イディオタイプ・モノクローナル抗体}

\author{
过崎正幸*1), 今井浩三・本谷 聡・日野田裕治・谷内 昭*27
}

\begin{abstract}
Analysis of anti idiotypic monoclonal antibodies and their application in tumor immunology

Id-anti-Id interaction constitutes an immune network that is involved in the regulation of the immune response. We prepared several anti-Id mAb to anti-CEA $\mathrm{mAb}$ MA 208 which was found to recognize the peptide of CEA. These anti-Id mAb were then used for idiotope mapping and for developing anti-anti-Id antibodies to analyze the Id network system relating to CEA. Anti-anti-Id mAb M 7-625 antisera $(\mathrm{Ab} 3)$ reacted with purified CEA in binding assay and in Western blot analysis, and competed with $\mathrm{Ab} 1$ binding to $\mathrm{CEA}$.

It is indicated that $\mathrm{Ab} 2$ mimicks the structure of the epitope in CEA which was recognized with $\mathrm{Abl}$. These serologic findings suggest that anti-ld $\mathrm{mAb} M \mathrm{M}-625$ carries the internal image of the Ag. According to the amino acid sequences of CDR 1,2 , and 3 of the mAb M 7-625 variable region, there exists a homology of amino acid sequences between CDR 2 in the $\mathrm{H}$ chain (5 amino acids of 10) and CDR 3 in the $\mathrm{L}$ chain (3 amino acids of 9) of mAb M 7-625 and domain III of CEA (545-554).

Internal image bearing anti-Id antibodies may be useful for the induction of a host's immune response against tumors.
\end{abstract}

Masayuki Tsujisaki*1), Kohzoh Imai .

Satoshi Motoya $\cdot$ Yuji Hinoda $\cdot$ Akira Yachi ${ }^{* 2}$

key words : idiotype network system,

anti-idiotypic monoclonal antibodies, internal image of antigen

idiotype network theory は免疫学に大きな impactを与えたばかりでなく, 自己免疫疾患、レ セプター病などの病因解析にも導入され成果を得 ている.さらに細菌感染あるいは HIV を含むウ イルス感染症 ${ }^{1}$, 寄生虫感染に対するワクチン実 験に成功を収めている.

一方, 腫瘍におけるイディオタイプ研究が散見 されるが，筆者らは，これまでに抗イディオタイ プ(Id)モノクローナル抗体 $(\mathrm{MoAb})$ を各種の腫㾨 関連抗原系において確立し, 癌の診断・治療への 応用の可能性について検討を行ってきた，本稿で は, 筆者らの成績を加えつつイディオタイプ研究 を概観し, 腫瘍免疫におけるイディオタイプ・ネッ トワークの有用性について述べたい.

*1) Department of Internal Medicine Tenshi Hospital 天 使挍院内科

*2) Department of Internal Medicine (Section 1), Sapporo Medical College 柇蜆医科大学第一内科学数室

\section{イディオタイプ・ネットワーク}

(1) イディオタイプ(idiotype) とは

抗体が抗原と特異的に結合するのは, 抗体の可 変部領域 (variable region), 特に超可変部領域 (hypervariable region)が抗原表面に存在する抗 原決定基(エピトープ)を認識するための異なった 構造を持つことに由来する。このような抗体の異 なった構造，すなわち抗体の個々の“顔”をイディ オタイプと定義する.さらに, このイディオタイ プはエピトープと相補的構造にあるパラトープと 多くのイディオトープの集合体として形成されて いる(図 1).

(2) Idiotype network theory

Jerne はこれらのイディオタイプを介して免疫 系が調節され, 生体の恒常性維持を担っている可 能性を考え, 以下の 3 点からなる idiotype network theory を提唱した.

(1) 抗体分子はパラトープを介して他者のエピ 


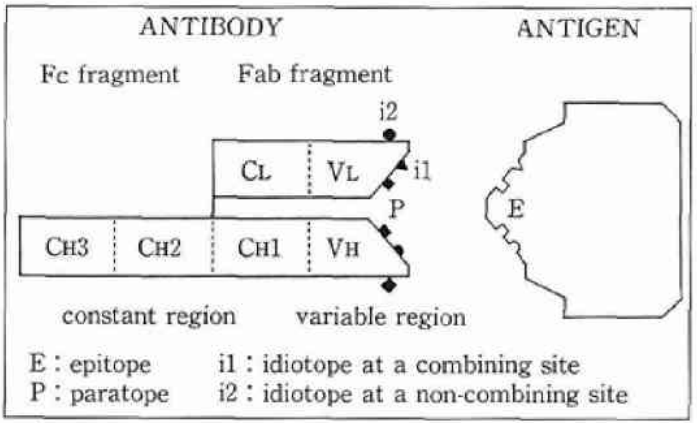

图 1 抗原と抗体可変部領域に扔けるイディオタイブ 構造

トープを認識するのと同時に，イディオトープを 介して認識される(二面性).

(2) エピトープあるいはイディオトープはパラ トープに対し刺激的に作用し，イディオトープに 対する抗イディオタイプ反応は抑制的に作用する (ホメオスターシス).

(3) 免疫系が種々のイディオトープとパラトー プ間の相互作用を基盤としたネットワークを形成 することによりバランスを保っており内部抗原が 相互に認識し, 認識されることにより免度系の拡 がりを維持している。よって外来抗原は平衡が保 たれているネットワークを乱すものとして位置付 けし, 免疫系は外へ向けられた系ではなく内部に 向けられた相互作用により成立している.

この仮説は今日，免疫学の基本概念として受け 入れられており, 免疫系の調節機構において idiotype network が重要な役割を担っていることは 疑いがない.

\section{腫瘍免疫における抗イディオタイプ抗体の応用}

腫瘍免疫における抗 Id 抗体の応用は広い範囲 にわたっている(表1).

血中に存在する腫瘍関連抗原 (tumor associated antigen, TAA)の検出, あるいは宿主が TAA に対する抗体を産生する場合にも，その抗体の検 出が可能であり, 新しい癌診断アプローチになり うる。

一方，イディオタイプ解析に基づく抗原あるい は抗体の構造の検索が可能であり, さらに最大の 関心事であるところの癌治療への応用の可能性も 期待されている.
表 1 腄癌免度における抗イディオタイプ抗体の応用

1) analysis of fine structure Idiotype mapping of antibody Analysis of internal image

2) diagnosis Detection of circulating tumor associated antigen(TAA), anti-TAA antibody and immune complex

3) therapy Induction of humoral and cellular immunity vaccination

（1）抗イディオタイプ抗体を利用した癌診断 抗Id抗体を用いて血清中に存在する遊離 TAA，抗 TAA 抗体，およひ両者が結合した免疫 複合体の新しい検出法の開発を試みた.

癌胎児性抗原 (CEA)について, 抗 Id MoAb を 用いて血中 $\mathrm{CEA}^{21}$, 宿主が産生する抗 $\mathrm{CEA}$ 抗体 さらに CEA-抗 CEA 抗体からなる免疫複合体の 測定系を確立した。

(2) 抗 Id MoAb を用いた CEA 抗原の検出 遊離型 CEA 抗原の検出には, 既報引に示すごと く抗 CEA MoAb 5 B 3 の抗原結合部位に関係し た抗 Id MoAb T 4-305 を用いた.この独自の抗 原検出法は, idiotype-anti-idiotype interaction の阻止率をみるものであり, 従来法の double determinant immunoassay (DDIA) とは異なって いる(図 2).

そこで, CEA 産生および非産生各種培養細胞の 培養上清を用いて, 存在する遊離 CEA 量を測定 した. 図 3 に示すように抗 Id MoAb を用いた阻 止反応は DDIA 法の結果と有意の相関関係を示 し，抗原量を反映していると考えられた。

一方, 精製 CEA を用いて抗 Id 抗体阻止反応 系を適応すると, 直線関係が得られ, 阻止率は遊 離 CEA 量に比例して増加していた.

(3) 抗 CEA 抗体および CEA - 抗 CEA抗体 複合体の検出

一方, 抗 Id MoAb を用いて患者血清中の抗 CEA 抗体を測定する系を確立し，覀性疾患，主に 消化器癌患者について検討した，抗 CEA 抗体を 認める症例は $10 〜 50$ 万分の 1 と,まれであること が以前に報告されているが，筆者らの系でも進行 癌では抗 CEA 抗体を認める例はほとんどなかっ 


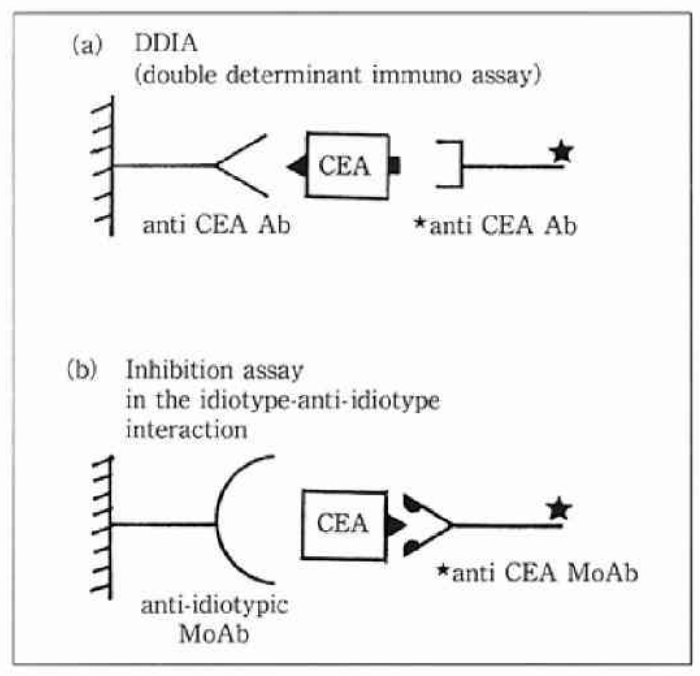

图 2 遊崔型腄鶟関連抗原の検出法

a : DDIA 法(星印は ${ }^{125}$ - 標識 anti CEA Ab)

b : 抗 Id 抗体を用いた inhibition assay(星印は ${ }^{125}$ - 標䜟 anti CEA MoAb)

た、しかし, 遊離抗体ではなく免疫複合体として 検出される例が見出され，興味深い.

Fuchs ら () $^{4}$ CEA の免疫複合体について報告 しているが、筆者らは抗 Id 抗体を用いた兔疫複合 体の新しい検出法を確立することができたため, いかなる腫㾂関連抗原が担癌宿主に抗体産生を誘 導するのかについて検討し癌に対する免疫応答の 機序解析に今後, 応用することを考えている.

\section{イディオタイプ・ネットワークシステムの解析}

CEA 抗原系におけるイディオタイプ解析を抗 イディオタイプ・モノクローナル抗体を多数確立 し以下のごとく行った ${ }^{5)}$.

(1) 抗イディオタイプモノクローナル抗体の 作製

抗 CEA MoAb MA 208 をマウスに同系免疫し 型のごとく細胞融合を行った. 固相化 CEA と ${ }^{125}$ I-標識 MoAb MA 208 の結合阻害をみる inhibition assay により, MoAb MA 208 の抗原結合 部位のイディオトープを認識する抗 Id 抗体産生 ブリドーマのスクリーニングをした，得られた 5 種の ${ }^{125}$ I-標識抗 Id MoAb を用い, MA 208 との 反応性および各種 MoAb との交差反応性を検討 した、それぞれの抗 Id MoAb は免疫原である

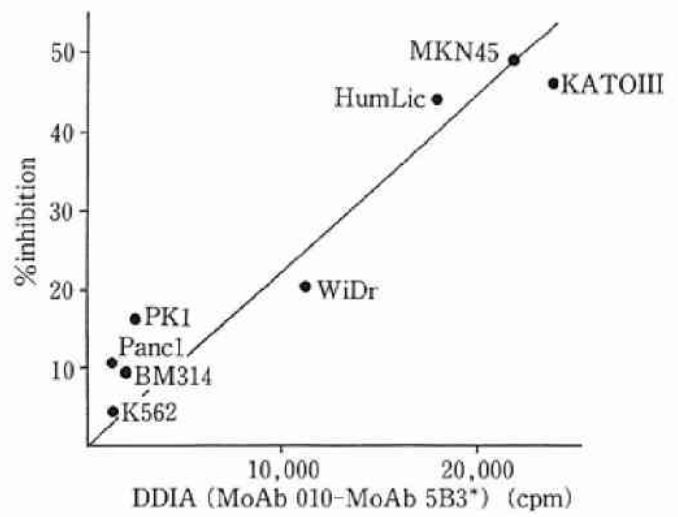

図 3 避離 CEA 測定における DDIA と抗 Id 抗体を用いた inhibition assay の関係

MA 208 とのみ特異的に反応し, その他の抗 CEA, 抗 NCA および抗 MAA(メラ)ーマ関連抗 原) $\mathrm{MoAb}$ などに対して反応性を認めなかった (表 2).

以上の結果より，それぞれの抗 Id MoAb が認 識する epitope は MoAb MA 208 上の抗原結合 部位に存在する idiotope であることが示唆され た.

(2) 抗・抗イティオタイプ抗体の誘導と, そ の特異性

5 種の抗 Id MoAb をそれぞれ同系免疫し，抗 血清を sandwich assay を用いて解析した。 免疫 原である抗 Id MoAb と反応する特異的抗・抗 Id 抗体が誘導されていることが示唆されるととも に, M 7-413 と M 7-914 および M 7-049 と M 7418 に交差反応性を認め, shared idiotope の存在 が推測された(表 3 ).

(3) 抗原に反応する $\mathrm{Ab} 1$ like $\mathrm{Ab} 3$ の検出 これらの抗 Id MoAb はMA 208 の抗原結合部 位を認識していることから MA 208 の paratope を介して, CEA の内部イメージを有する可能性が ある. 理論上 CEA の内部イメージを持つ抗 Id 抗 体から誘導された抗・抗 Id 抗血清中に, もとの抗 CEA MoAb MA 208 と同様の特異性を有する population (Ab 1 like $\mathrm{Ab} 3$ ) の存在を認めるかを, binding assay および Western blot analysisを用 いて検討した.

抗 Id MoAb M 7-625 により誘導された抗血清 は, 他の抗血清および正常血清と異なり, 固相化 
表 2 Specificity of monoclonal anti-idiotypic antibodies elicited with anti-CEA MoAb MA208*1)

\begin{tabular}{llccccc}
\hline \multirow{2}{*}{ MoAb } & \multirow{2}{*}{ specificity } & \multicolumn{5}{c}{${ }^{125}$ I-labeled anti-idiotypic MoAb } \\
\cline { 3 - 7 } & & M7-049 & M7-413 & M7-418 & M7-625 & M7-914 \\
\hline MA208 & CEA & $80.7^{* 2)}$ & 12.7 & 46.9 & 59.8 & 49.9 \\
5B3 & CEA & 1.2 & 0.9 & 1.0 & 1.1 & 0.8 \\
10 & CEA & 0.5 & 0.3 & 0.4 & 0.3 & 0.7 \\
YK024 & CEA & 0.5 & 0.4 & 0.3 & 0.4 & 0.5 \\
MA503 & NCA & 0.6 & 0.4 & 0.5 & 0.4 & 0.7 \\
YH206 & Mucin & 0.7 & 0.4 & 0.5 & 0.4 & 0.8 \\
BM2 & X-hapten & 0.4 & 0.4 & 0.4 & 0.4 & 0.6 \\
225.28 & HMW-MAA & 0.6 & 0.3 & 0.4 & 0.4 & 0.7 \\
HA58 & ICAM-I & 0.4 & 0.3 & 0.3 & 0.3 & 0.6 \\
CR11-115 & HLA-class I & 0.6 & 0.5 & 0.4 & 0.4 & 0.5 \\
KSI & HLA-A2, A28 & 0.5 & 0.4 & 0.4 & 0.4 & 0.5 \\
\hline
\end{tabular}

*1) ${ }^{128}$ I-labled monoclonal anti-idiotypic antibodies were incubated for 3 hours at $4^{\circ} \mathrm{C}$ with monoclonal antibodies coated microtiter plates. Then plates were washed and bound radioactivity was counted in a $\gamma$-counter.

*2) Results are expressed as $\mathrm{cpm} \times 10^{3}$.

表 3 Analysis of anti-anti-idiotypic antisera generated with anti-idiotypic mAb to anti-CEA mAb MA208

\begin{tabular}{|c|c|c|c|c|c|}
\hline \multirow{2}{*}{$\begin{array}{c}\text { anti-idiotypic } \\
\mathrm{mAb}(\mathrm{Ab} 2)\end{array}$} & \multicolumn{5}{|c|}{ anti-anti-idiotypic antiserum (Ab3) generated with } \\
\hline & M7-625 & M7-413 & M7-914 & M7-049 & M7-418 \\
\hline \multicolumn{6}{|c|}{ sandwich assay } \\
\hline M7-625 & $\underline{22495} \mathrm{cpm}^{*}$ & $647 \mathrm{cpm}$ & $777 \mathrm{cpm}$ & $839 \mathrm{cpm}$ & $1001 \mathrm{cpm}$ \\
\hline M7-413 & 300 & 17115 & $\underline{7852}$ & 291 & 499 \\
\hline M7-914 & 394 & $\underline{5032}$ & $\underline{21197}$ & 524 & 749 \\
\hline M7-049 & 659 & 965 & 739 & $\underline{11446}$ & $\underline{4737}$ \\
\hline$M 7-418$ & 388 & 731 & 423 & $\underline{10434}$ & 6991 \\
\hline
\end{tabular}

- Anti-anti-idiotypic antisera were incubated with anti-idiotypic mAb coated on microtiter plates, and then the reactivity of ${ }^{125}$ I-labeled monoclonal antiidiotypic antibodies was tested in sandwich assay. The results are expressed as bound $\mathrm{cpm}$. Positive results are marked by underlining

CEA と結合反応し(図 4)さらに Western blot-

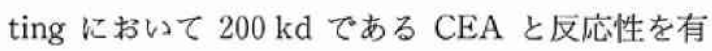
していた(図 5).

一方, 還元・非還元下で行った Western blot analysis により抗 Id MoAb M7-625 は還元下で MoAb MA 208 との反応性を失った(図 6).これ は CEA 構造が抗 Id 抗体の heavy 鎖と light 鎖 の両方に shareされていることを推測させた，以 上の結果より, 抗 Id MoAb M 7-625 は CEA の internal image を有する抗体であることが示唆さ れた.

\section{(4) internal image の構造解析}

抗 Id MoAb M 7-625 の有する抗原の internal image がどのような構造として CEA 抗原を mimic しているかを検索した ${ }^{6)}$. heavy chain お よび light chain の variable region のクローニン グに PCR 法を利用し, cDNA を得, vector に ligation Lた. V領域 FR(framework region) 1 $\sim 3$, CDR (complementary determining region) 1 〜3 のDNA およびアミノ酸配列を決定した. 同様 に internal imageをもたない抗 Id MoAb M 7049 もクローニングした. 
抗 Id MoAb M 7-625, M 7-049 の VH 領域は それぞれ subgroup II (A)に属し(図 7)，VL領域 は kappa light chain group 3 , および group 5 で あった. そこで抗原 CEA と抗 Id MoAb M 7-625, M 7-049 の VH, VL 領域のアミノ酸ホモロジー㭘

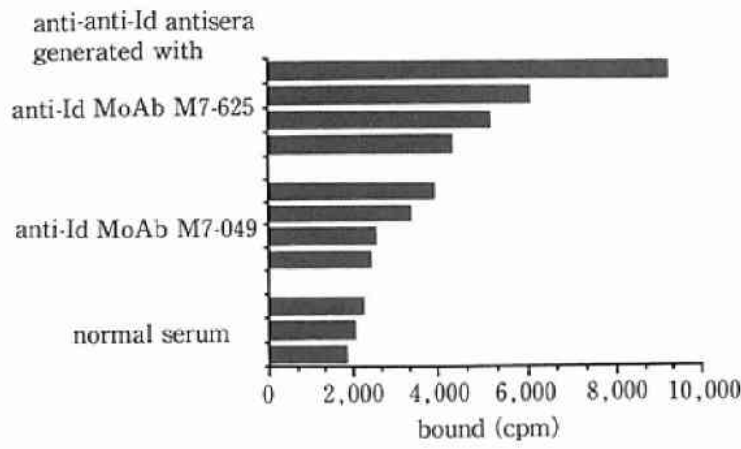

図 4 Reactivities of anti-anti-Id antisera generated with anti-Id $\mathrm{mAb} \quad \mathrm{M} 7-625(\mathrm{n}=4)$ and M7-049 $(n=4)$ to purified CEA. Normal $\operatorname{serum}(n=3)$ was used as a nega. tive control.

1

2

3

(Kd)

$200-$

$116-$

97-

$66-$

43-
1.

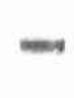

索をすると図 8 に示すごとく internal image を 有する抗 Id MoAb M 7-625 の VH・CDR 2(アミ ノ酸 NO. $57 \sim 66$ ) と CEA domain III(アミノ酸 NO. 545〜 554)に5個のアミノ酸一致を認めた. 一方, imternal image を持たない抗 Id MoAb M 7-049 は CEA とのホモロジーを有していなかっ た。図には示していないが, 同様の検索から，M 7-625 のVL・CDR 3 においても 3 個のアミノ酸 一致を認めた. 寸なわち CEA の構造は抗 Id $\mathrm{MoAb}$ のおよび L chain の両鎖にまたがって mimic されていることが推測された(図 9).

\section{抗イディオタイプ抗体を用いた癌治療}

以上示したごとく, 腫湯関連抗原系においても, 確実にイディオタイプ・ネットワークシステムが 存在し, さらに抗 Id 抗体に腫瘍抗原の構造が mimic されていることが示唆された。 したがっ て, 癌治療の一つのアプローチとして抗イディオ タイプ抗体の利用が考えられる。

腫瘍に対する抗 Id 抗体の治療法は大きく 2 種 に分類できる。一つは passive immunotherapy と

4

5

6

7

$$
\begin{array}{lllllll}
\text { Anti-CEA } & \text { Anti-MoAb } & \text { Anti-MOAb } & \text { Anti-CEA } & \text { Anti-MoAb Anti-MoAb Preimmune } \\
\text { MoAb 5B3 } & \text { T3-503 } & \text { T4-202 } & \text { MOAb } & \text { M7-049 } & \text { M7-625 } & \text { serum }
\end{array}
$$

図 5 Western blot analysis of binding actvities of anti-anti-idiotypic MoAbs T3-503(lane 2).

T4-202 (lane 3), M7-049 (lane 5), and M7-625 (lane 6) antisera to purified CEA.

Lane 1 (anti-CEA MoAb 5B3), lane 4 (anti-CEA MoAb MA208), and lane 7 (preimmune serum) are tested for binding to CEA as controls. 


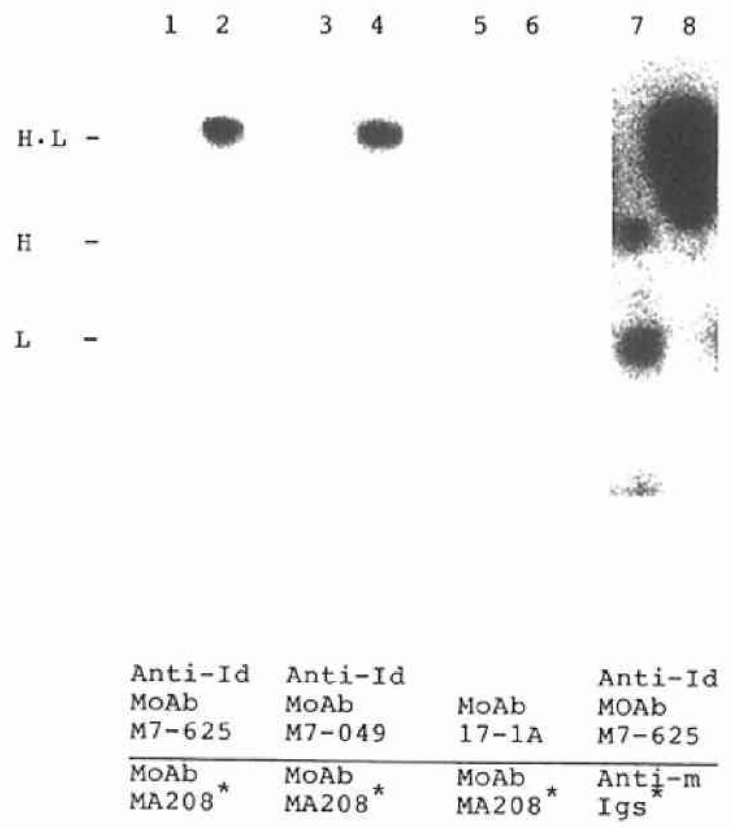

图 6 Western blot analysis for Id anti-Id interaction Anti-Id mAb M7-625(lanes 1 and 2), M7-049 (lanes 3 and 4), and irrelevant $\mathrm{mAb} 17-1 \mathrm{~A}$ (lanes 5 and 6) were tested for binding activity with ${ }^{125} \mathrm{I}$-labeled $\mathrm{mAb}$ MA208. Reactivity of anti-Id mAb M7-625 with ${ }^{125} \mathrm{I}-$ labeled anti-mouse Ig antibodies(lanes 7 and 8) was assessed by Western blot $(7.5 \%$ gel). (Lanes $1,3,5$, and 7 : reducing condition, lanes $2,4,6$, and 8 : nonreducing condition: $\mathrm{H} \cdot \mathrm{L}$, nonreducing, whole $\mathrm{Ig}$ ).

しての targeting 療法であり, もう一つは im. munomodulation を誘起する active immunotherapy である.

（1）抗 Id 抗体によるターケ゚ティング療法

単クローン性に増殖する腫湟である B cell lymphoma では, 腫瘍細胞表面に immunog$\operatorname{lobulin}(\mathrm{Ig})$ を表現している。この Ig は正常細胞 には存在せず, 腄瘍細胞クローンに特有な Id を有 しているために, 一種の腫瘍特異抗原と考えられ る.この Id に対して抗 Id 抗体を作製し，投与寸 れば特異性の面で理想的な targeting 療法となり うる.

この視点にたち, B cell lymphoma 症例に対し, Levy ら ${ }^{7}$ は抗 Id MoAb を用いた一連の targeting therapy を施行した. 完全宽解例をはじめと して腫瘤縮少を認めるなどの成果を得ている。詳 細は他書8を参照されたい.

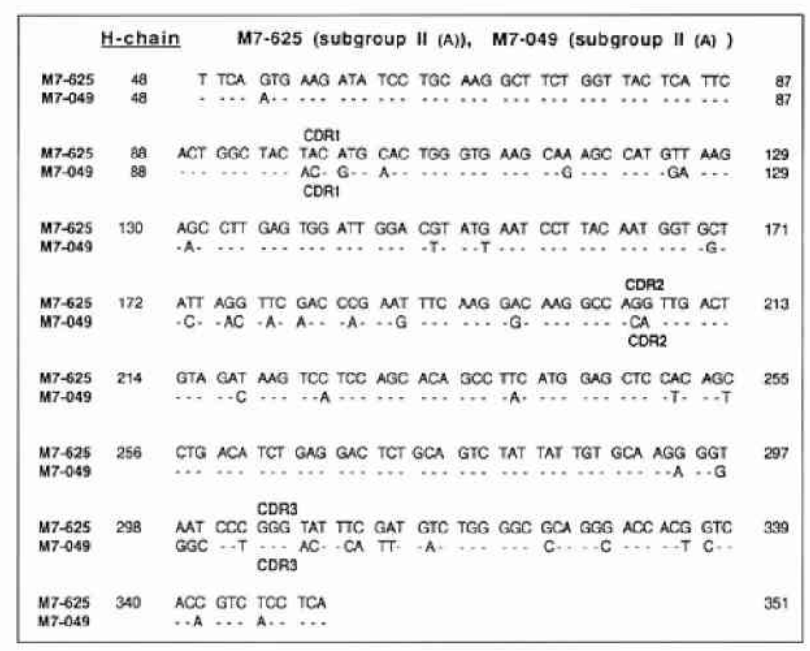

图 7 Nucleotide sequence of the VH cDNA of anti-ld mAb M7-625 and M7-049

The subgroups of mAb M7-625 and M7-049 are both group II (A).

\begin{tabular}{|c|c|c|c|c|c|}
\hline $\operatorname{cEA}$ & Domain III & 538 & O IQNSVS 凡NR & $8 D V+L D$ & 55 a \\
\hline$M 7-625$ & $\operatorname{con} 2$ & 50 & 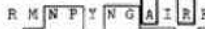 & 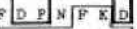 & 66 \\
\hline n7-0.49 & $\operatorname{CDR} 2$ & 50 & $L I N P Y N G G=N$ & $\mathbb{N} Q x P K a$ & 66 \\
\hline MOPC $104 E$ & $\operatorname{COR} 2$ & 50 & D I I N P P $]$ & $\because \mathrm{NQKYKG}$ & \\
\hline M7-625 & $\mathrm{CDR} 3$ & 99 & E:N:PO: YPDV & 106 & \\
\hline $1 \times 7-049$ & $\mathrm{CDR} 3$ & 98 & 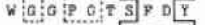 & 107 & \\
\hline MOPC1OAE & $\mathrm{CDR} 3$ & 99 & $D Y D W \quad Y P D V$ & 106 & \\
\hline
\end{tabular}

区 8 The compared sequences of the $\mathrm{VH} \cdot \mathrm{CDR} 2$ or CDR3 of internal image bearing anti-Id $\mathrm{mAb}$ M7-625, internal image nonbearing anti -Id mAb M7-049, irrelevant mAb MOPC $104 \mathrm{E}$ and CEA domain III

The subgroup of these three $\mathrm{mAb}$ is group II (A). The amino acid sequences (nos. 57-66) within VH . CDR2 of anti-Id mAb M7-625 are unique and different from those of irrelevant $\mathrm{MAb}$ MOPC 104, and furthermore those $\mathrm{AA}$ are identical to those of $\mathrm{CEA}$ domain III. However, those of $\mathrm{VH} \cdot \mathrm{CDR} 3$ of $\mathrm{mAb}$ M7-049 are unique, but no homologous to CEA is found.

\begin{tabular}{|lrrr|}
\hline $625 \mathrm{VH}$ CDR2 & 50 & RMNPYNGAIRFDPNFKD & 66 \\
$\mathrm{CEA}$ & 538 & GIQNSVSANRSDPVTLDVLY & 557 \\
$625 \mathrm{VL} \mathrm{CDR3}$ & 89 & QQSNEDPFT & 97 \\
\hline
\end{tabular}

图 9 The compared sequences of the VH $\mathrm{CDR} 2$ and $\mathrm{VL} \cdot \mathrm{CDR} 3$ sequence of antiId mAb M7-625 and the third domain of CEA

The amino acids marked by asterisk are identical. 
- biological response modifiers (BRM)

BRM

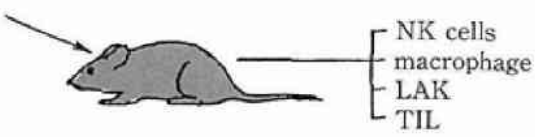

TIL

- targeting therapy with monoclonal antibodies (MoAbs)

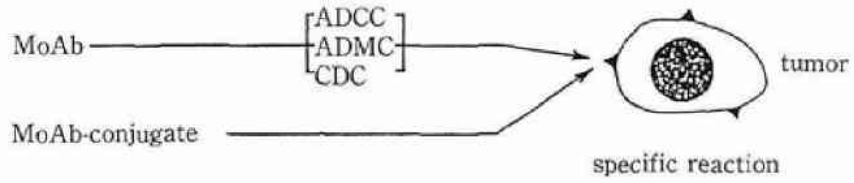

- Ag specific immunodulation with anti-Id MoAbs

anti-Id MoAbs (Ab2)

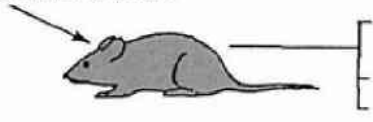

anti-anti-Id Abs (Abl like $\mathrm{Ab} 3$ ) CTL helper $\mathrm{T}$ cells

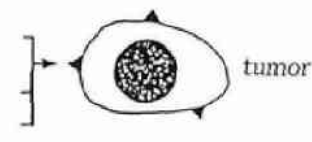

specific reaction
図 10

癌免疫療法の新しい

アプローチ

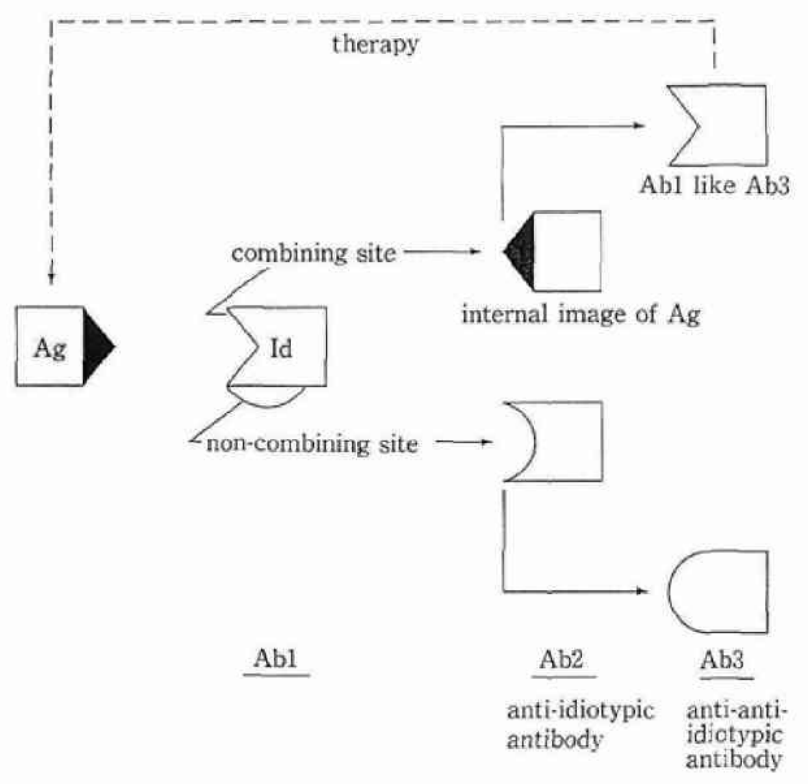

图 11 Idiotype network system in tumor associated antigen

\section{（2）抗 Id 抗体を用いた免疫誘導療法}

上述の targeting therapy は MoAb を腫瘍細 胞表面に特異的に結合させたあと, 補体， T細胞 とともに CDC, ADCC などの cytotoxic mechanism による臨床効果を期待するものであった.

これに対し，抗 Id 抗体を投与することにより生 体に immunomodulation を与える active im- munotherapy は, 嗹鈞特異的な宿主自身の抗体産 生(液性免疫), あるいは特異的な $\mathrm{T}$ cell 系の誘導 (細胞性免疫) を惹起するなど, イディオタイプを 介した免疫応答を利用しようというものである。

(1) 抗 Id 抗体療法の特徵

抗 Id 抗体を用いた免疫療法は図 10 に示すよう に，抗原・非特異的免疫応答をホストに誘導する BRM (biological response modifier) と抗原特異 的な抗体を受働免疫し, 抗体の抗原への直接結合 を介した抗腫瘍効果をねらう targeting therapy をあわせたようなアプローチである.

(2) 腫瘍関連抗原系におけるイディオタイプ・ ネットワークシステム

図 11 に腫瘍抗原をめぐるイディオタイプ・ネッ トワークについて示した，ある腫激関連抗原を認 識する抗体 $(A b$ 1) を免疫すると, Ab 1 特異的な 抗 Id 抗体 $(\mathrm{Ab} 2)$ が誘導される。これら抗 Id 抗 体・Ab 2 の中には Ab 1 の paratope を介して抗 原の内部イメージ(internal image of antigen)を 持つ $\mathrm{Ab} 2$ が存在する. 理論上, 抗原の internal image を有する抗 Id 抗体を免疫することにより 誘導される抗・抗 Id 抗体(Ab 3)には，もとの抗 原と反応し, $\mathrm{Ab} 1$ と同様の特貲性を有する抗体 (Ab 1 like $\mathrm{Ab} 3$ ) の population が含まれる。よつ て, internal image を有する $\mathrm{Ab} 2$ を免疫すれば 抗原に反応する $\mathrm{Ab} 3$ を誘導することか゚可能とな 
り，抗腫瘍機序を期待できる。この場合, $\mathrm{Ab} 2$ は 液性免疫のみならず抗原特異的 helper $\mathrm{T}$ cell $^{9)}$, $\mathrm{CTL}^{10)}$ などの抗腫瘍 $\mathrm{T}$ 細胞の誘導をも可能にし ているという報告もある.

\section{まとめ}

以上示したごとく, 腫瘍抗原系において, 抗 Id 抗体は腫瘍関連抗原，これに対する抗体および免 疫複合体の検出などの癌診断に応用することがで きる、また，イディオタイプ・マッピングを主体 とした抗体あるいは抗原の構造解析を可能にす る.さらに CEA を用いた解析から, 腫瘍関連抗 原系においても idiotype network system が成立 し, 血清学的検查㧍よびクローニングから, ある 特定の抗 Id 抗体が抗原の internal image を有す ることが示唆された。

一方, in vivo 実験において internal image を 有すると考えられる抗 Id MoAb がメラノーマ同 系移植腫瘍に対し, 部分的なワクチン効果を認め ること的, あるいは Ferrone ら ${ }^{12)}$ が悪性メラノー マ患者に抗 Id MoAb を用いた phase 1 trial を行 い治療効果を認めるなどの報告がある、このよう に抗 Id 抗体による active immunotherapy は, idiotype network system を介して宿主に antigen specific immunomodulation をちえる可 能性があり, 今後, 癌免疫療法の一つとして期待 される。

\section{文 献}

1) Zhou, E-M., Lohman, K. L., kennedy, R. C. : Administration of noninternal image monoclonal anti-idiotypic antibodies induces idiotyperestricted responses specitic for human immunodeficiency virus envelope glycoprotein epitopes. Virology 174, 9-17, 1990.

2）过崎正幸, 日馬幹弘, 今井浩三・他：抗イア゙イオタイ プモノクローナル抗体による遊離腄癌関連抗原の検 出. 医学のあめみ $142: 251-252,1987$,

3) Tsujisaki, M., Imai, K., Tokuchi, S., Masuya, J.,
Ishida, T., Adachi, M., Hinoda, Y., Hanzawa, Y., Yachi, A. : New assay to detect shedding antigen with use of anti-idiotypic monoclonal antibodies. J. Clin. Lab. Analysis 5:14-20, 1991.

4) Fuchs, C., Krapf, F., Kern, P. et al : CEA-containing immune complexes in sera of patients with colorectal and breast cancer. Cancer Immunol. Immunother. $26: 180-184,1988$.

5) Tsujisaki, M., Imai, K., Tokuchi, S., Hanzawa, Y., Ishida, T., Kitagawa, H., Hinoda, Y., Yachi, A. : Induction of antigen-specific immune response with use of anti-idiotypic monoclonal antibodies to anticarcinoembryonic antigen antibodies. Cancer Res. $51: 2599-2604,1991$.

6) Tsujisaki, M., Hinoda, Y., Tokuchi, S., Hanzawa, Y., Arimura, Y., Masuya, J., Kitagawa, H., Okochi, E., Shimamura, T., Hamuro, J., Imai, K., Yachi, A. : The analysis of internal image-bearing antiidiotypic monoclonal antibody in relation to CEA. J. Immunol. 150 : 508-516, 1993.

7) Meeker, T. C., Lowder, J., Maloney, D. G., Miller, R. A., Thielemans, K., Warnke, R, Levy, R. : A clinical trial of anti-idiotype therapy for B cell malignancy. Blood $65: 1349-1363,1985$.

8) Brown, S. L., Miller, R. A., Levy, R. et al. : Treatment of B-cell lymphomas with anti-idiotype antibodies alone and in combination with alpha interferon. Blood $73: 651-661,1989$.

9) Saeki, Y., Chen, J. J., Shi, L. et al. : Idiotype-specific $T$ helper clones recognize a variable $H$ chain determinant. J. Immunol. $144: 1625,1990$.

10) Raychaudhuri, S., Saeki, Y., Chen, J. J. et al. : Tumor specific idiotype vaccines: II. Analysis of the tumor-related network response induced by the tumor and by internal image antigens ( $\mathrm{Ab} 2 \beta$ ). J. Immunol. $139: 271,1987$.

11）陣野原庸治, 过崎正幸, 槡沢義昭, 得地 茂, 石田禎 夫, 外谷治郎, 本谷 聡, 日野田裕治, 今井浩三, 谷 内 昭：メラノーマ抗原系におりる抗イディオタイフ のワクチン効果, DDS 8:27-31, 1993.

12) Mittelman, A., Chen, Z. J., Yang, H., Wong, G. Y., Ferrone, S. : Human high molecular weight melanoma-associated antigen(HMW-MAA) minicry by mouse anti-idiotypic MoAb MK 2-23: Induction of humoral anti-HMW-MAA immunity and prolongation of survival in patients with stage IV melanoma. Proc. Natl. Acad. Sci. USA 89 : 466470, 1992. 